\title{
GENETIC AND CLINICAL FEATURES OF HEMOGLOBIN H DISEASE IN CHINESE PATIENTS
}

\author{
Frederick E. Chen, M.D., Clara Ool, M.B., B.Ch., Sau Yin Ha, M.B., B.S., Bernard M.Y. Cheung, M.B., B.ChiR.,
} David Todd, M.D., Raymond Liang, M.D., Tal Kwong Chan, M.D., ANd Vivian Chan, Ph.D.

\section{ABSTRACT}

Background Normally, one pair of each of the two $\alpha$-globin genes, $\alpha 1$ and $\alpha 2$, resides on each copy of chromosome 16. In hemoglobin $\mathrm{H}$ disease, three of these four $\alpha$-globin genes are affected by a deletion, a mutation, or both. We studied the $\alpha$-globin gene abnormalities and the clinical and hematologic features of Chinese patients with hemoglobin $\mathrm{H}$ disease in Hong Kong.

Methods We assessed the clinical features, hematologic values, serum ferritin levels, and liver function of 114 patients with hemoglobin $\mathrm{H}$ disease. We also performed echocardiography and magnetic resonance imaging of the liver and examined the two pairs of $\alpha$-globin genes.

Results Hemoglobin $\mathrm{H}$ disease in 87 of the 114 patients (76 percent) was due to the deletion of three of the four $\alpha$-globin genes $(--/-\alpha)$, a combination termed the deletional type of hemoglobin $\mathrm{H}$. The remaining 27 patients (24 percent) had the nondeletional type of hemoglobin $\mathrm{H}$ disease, in which two $\alpha$-globin genes are deleted and a third is mutated $\left(--/ \alpha \alpha^{\top}\right)$. All 87 patients with the deletional type of hemoglobin $\mathrm{H}$ were double heterozygotes in whom there was a deletion of both $\alpha$-globin genes from one chromosome, plus a deletion of the $\alpha 1$ or $\alpha 2$ gene from the other chromosome $(--/ \alpha-$ or $--/-\alpha)$. A variety of mutated $\alpha$-globin genes was found in the patients with nondeletional type of hemoglobin $\mathrm{H}$ disease. Patients with the nondeletional type of the $\mathrm{H}$ disease had more symptoms at a younger age, more severe hemolytic anemia, and larger spleens and were more likely to require transfusions than patients with deletional hemoglobin $\mathrm{H}$ disease. The severity of iron overload was not related to the genotype.

Conclusions Chinese patients in Hong Kong with the nondeletional type of hemoglobin $\mathrm{H}$ disease have more severe disease than those with the deletional type of the disease. Iron overload is a major cause of disability in both forms of the disease. (N Engl J Med 2000;343:544-50.)

(C2000, Massachusetts Medical Society.

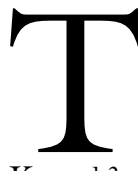

HE $\alpha$-thalassemias are the most common inherited disorders of hemoglobin synthesis in Southeast Asia and southern China. Their prevalence is 3 to 5 percent in Hong Kong ${ }^{1,2}$ and 30 to 40 percent in northern Thailand and Laos. ${ }^{3}$ These disorders arise from deletions or mutations (or both) of $\alpha$-globin genes, of which there are four in the normal genome. The clinical manifestations of these genetic abnormalities range from the silent carrier state, in which only one $\alpha$-globin gene is deleted, to fatal hydrops fetalis, in which all four $\alpha$-globin genes are missing. In hemoglobin $\mathrm{H}$ disease, a thalassemia of intermediate severity, three of the four $\alpha$-globin genes are affected.

The hemoglobin molecule is a tetramer consisting of two $\alpha$-globin chains and two $\gamma$-globin chains (which form fetal hemoglobin in the fetus) or two $\alpha$-globin chains and two $\beta$-globin chains (which form hemoglobin $\mathrm{A}$ in the adult). Balanced synthesis of these chains ( $\alpha$ and $\gamma$ or $\alpha$ and $\beta$ ) in erythroblasts is important for the production of hemoglobin and the integrity of the erythrocyte. In the $\alpha$-thalassemia syndromes, there is an imbalance of globin-chain synthesis as a result of a deficiency of $\alpha$-globin chains, and the hematologic abnormalities of the disease reflect the extent of the imbalance. In addition to the reduced hemoglobin formation caused by decreased production of $\alpha$-globin chains, an excess of $\beta$-globin or $\gamma$-globin chains accumulates in erythroblasts and forms tetramers. Hemoglobin $\mathrm{H}$ consists of tetramers of $\beta$-globin chains, ${ }^{4}$ and hemoglobin Bart's is composed of tetramers of $\gamma$-globin chains. ${ }^{5}$ Both tetramers are unstable; they precipitate inside erythroblasts and erythrocytes, causing lysis of the cells. ${ }^{6}$ Hemoglobin $\mathrm{H}$ disease and hemoglobin Bart's hydrops fetalis are highly prevalent in southern China and Southeast Asia. In Hong Kong, the incidence of hemogloblin $\mathrm{H}$ disease is approximately 6 in 10,000 live births, with 48 affected babies born annually.

At the end of its short arm, chromosome 16 contains a cluster of related genes, which include the two $\alpha$-globin genes, $\alpha \mathrm{l}$ and $\alpha 2$. The $\alpha$-globin genotype of a normal diploid cell is therefore $\alpha 2 \alpha \mathrm{l} / \alpha 2 \alpha \mathrm{l}$; each pair of the closely linked $\alpha 1$ and $\alpha 2$ genes is usually inherited as a unit, called a haplotype. There are two types of genetic abnormalities in $\alpha$-thalassemia: in the first, both $\alpha$-globin genes on the same chromosome are deleted $(--/)$, and in the other, only one $\alpha$-globin gene is affected, either by a deletion or by a nondeletional defect (usually a point mutation). In hemoglobin $\mathrm{H}$ disease, three of the four $\alpha$-globin genes are affected. This results from double heterozygosity for either the $(--/)$ haplotype plus the $(/-\alpha)$ haplotype (resulting in a genotype of $--/-\alpha$, to indicate

From the Departments of Medicine (F.E.C., B.M.Y.C., D.T., R.L., T.K.C., V.C.), Radiology (C.O.), and Paediatrics (S.Y.H.), University of Hong Kong and Queen Mary Hospital, Hong Kong, China. Address reprint requests to Dr. Vivian Chan at the University Department of Medicine, Queen Mary Hospital, Pokfulam Rd., Hong Kong, China, or at vnychana@ hkucc.hku.hk. 
deletions of both $\alpha$-globin genes from one chromosome and the deletion of a single $\alpha$-globin gene from the other), or the $(--/)$ haplotype plus the $\left(/ \alpha \alpha^{\mathrm{T}}\right)$ haplotype (resulting in a genotype of $--/ \alpha \alpha^{\mathrm{T}}$, in which $\alpha^{\mathrm{T}}$ indicates the defective $\alpha$-globin gene) (Fig. 1). This genetic heterogeneity contributes to the phenotypic diversity of hemoglobin $\mathrm{H}$ disease.

We assessed the clinical features and $\alpha$-globin gene abnormalities in Chinese patients with hemoglobin $\mathrm{H}$ disease in Hong Kong in order to provide a rational basis for the prevention and management of the disease. Iron overload is common among older patients (age, 35 or older) who have hemoglobin $\mathrm{H}$ disease, ${ }^{7-9}$ and given the aging population in Hong Kong and in other Chinese communities, this complication may become a public health problem.

\section{METHODS}

\section{Patients}

The medical records of 114 Chinese patients with hemoglobin $\mathrm{H}$ disease were reviewed between January 1998 and December 1999. There were 93 adults and 21 children; 51 ( 45 percent) were male, and 63 (55 percent) were female. The patients ranged in age from newborn to 80 years. The majority of patients came from the Pearl River delta area of Guangdong province in southern China. A few were from the neighboring provinces of Guangxi and Fujian, and one was from Henan in central China.

\section{Phenotypic Analysis}

\section{Clinical Assessment}

The following were determined: age at diagnosis, symptoms at presentation, drug and transfusion histories, and whether the patient had undergone splenectomy. Each patient underwent a physical examination during a routine follow-up visit in which height, the presence or absence of jaundice, and the size of the spleen and liver were determined. A total of 80 patients were tested for hepatitis B antigen, for which 9 were positive, and hepatitis $\mathrm{C}$ antibody, for which none were positive.

\section{Hematologic Measurements}

The hemoglobin level and red-cell indexes were determined with an electronic cell counter (model S, Coulter Electronics). Hemoglobin electrophoresis was performed on cellulose acetate ( $\mathrm{pH} 8.5$ ); the hemoglobin $\mathrm{H}$ bands and other hemoglobin bands were quantified by means of elution. Hemoglobin $\mathrm{A}_{2}$ was assessed by microcolumn chromatography, and fetal hemoglobin was assessed by measuring the level of alkali-resistant hemoglobin. Red cells were stained with 1 percent brilliant cresyl blue $(2: 1)$ in citrate-saline at $37^{\circ} \mathrm{C}$ for 30 minutes and then examined microscopically for hemoglobin $\mathrm{H}$ inclusions.

\section{Iron Studies}

Serum ferritin was measured with a chemiluminescence immunoassay (Corning Magic Lite and Chiron Diagnostics). Serum iron was analyzed by a colorimetric method (model 717, Hitachi and Boehringer Mannheim). Liver function, including measurement of aspartate aminotransferase, alanine aminotransferase, bilirubin, alkaline phosphatase, and lactate dehydrogenase, was assessed with use of a multichannel analyzer (model 747, Hitachi and Boehringer Mannheim).

\section{Magnetic Resonance Imaging}

Magnetic resonance imaging (MRI) studies were performed in 60 successive patients over the age of 18 years; a 1.5-T system (Signa, General Electric Medical Systems) was used. The paramag-

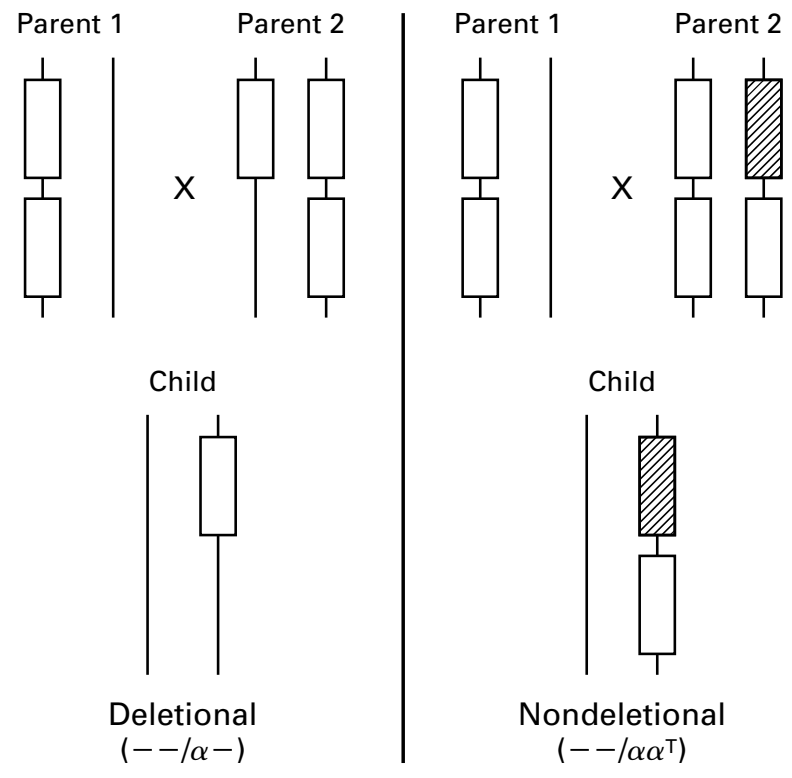

Figure 1. The Mode of Inheritance of Forms of Hemoglobin H Disease Involving Deletions and Other Types of Mutations.

The genotype of the parents is shown at the top. Normal $\alpha$-globin genes are represented by open boxes, and mutated, nondeleted $\alpha$-globin genes $\left(\alpha^{\top}\right)$ by hatched boxes. The genotypes of the offspring are shown in parentheses.

netic effects of iron reduce the signal intensity (resulting in hypointensity) in the affected organs. Iron overload is evaluated on the basis of the ratio of the signal intensity of a particular organ to the signal intensity of either fat or paraspinous muscle. A signal-intensity ratio of less than 1 indicates iron overload, and the $T_{2}$-weighted gradient-echo sequence has been shown to be the most efficient approach to determining the signal-intensity ratio. ${ }^{10-13} \mathrm{We}$ applied this validated method of iron quantification using paraspinous muscle as an internal standard for both qualitative assessment of iron overload (in which a grade of 1 was considered to indicate normal iron levels, a grade of 2 mild iron overload, a grade of 3 moderate iron overload, and a grade of 4 severe iron overload) and quantitative assessment of iron overload (defined as a signal-intensity ratio of less than 1 ) on $\mathrm{T}_{2}$-weighted images. ${ }^{10}$

\section{Echocardiography}

We performed echocardiography in 25 randomly selected patients who were older than 18 years of age ( 8 men and 17 women; mean $[ \pm S D]$ age, $48 \pm 16$ years) who had no history or signs of heart failure, using a computed sonograph (model $128 \mathrm{XP} / 10 \mathrm{C}$, Accuson). Left ventricular ejection fraction and blood flow across the mitral valve were measured with the use of pulsed Doppler ultrasonography. The peak early diastolic flow and the peak late diastolic flow were measured; a ratio of the peak velocity of blood flow across the mitral valve in early diastole to that in late diastole as a result of atrial contraction of less than 1 is suggestive of an impairment in left ventricular relaxation. Isovolumic relaxation time is the interval between the closure of the aortic valve and the opening of the mitral valve. An isovolumic relaxation time of more than $100 \mathrm{msec}$ is suggestive of abnormal left ventricular relaxation

\section{Liver Biopsy}

Liver biopsy was performed in six patients with elevated ferritin levels, abnormal liver function, or both. Liver iron content was quantitated by histologic grading of hemosiderotic granules. ${ }^{10}$ 


\section{Genotypic Analysis}

\section{Restriction-Endonuclease Mapping}

DNA from peripheral-blood leukocytes was digested with restriction enzymes BamHI, EcoRI, and BglII according to the manufacturer's instructions (New England Biolabs). Samples then underwent electrophoresis, Southern blotting, and hybridization to a $\zeta$-globin probe labeled with phosphorus-32 for the identification of gene deletions. ${ }^{1}$

\section{Allele-Specific Oligonucleotide Hybridization and Direct Genomic Sequencing}

For the detection of nondeletional defects, the $\alpha 2$ and $\alpha 1$ genes of the patients were specifically amplified by the polymerase chain reaction (PCR) ${ }^{14}$ and hybridized to oligonucleotides specific for the four common nondeletional $\alpha$-globin gene defects: the Constant Spring variant $\left(\alpha^{\mathrm{CS}}\right)$, in which CAA is substituted for TAA at codon 142 of $\alpha 2$ (TAA $\rightarrow$ CAA $)$; the Quong Sze variant $\left(\alpha^{\mathrm{QS}}\right)$ in which CCG is substituted for CTC at codon 125 of $\alpha 2$; the deletion of GAG ( $\triangle$ GAG) at codon 30 of $\alpha 2$; and the substitution of GAC for GGC at codon 59 of $\alpha 2 .{ }^{15}$

Unknown nondeletional defects were characterized by direct genomic sequencing of the PCR-amplified $\alpha 2$ and $\alpha 1$ genes. ${ }^{14}$

\section{Screening for Hereditary Hemochromatosis}

The 60 patients who underwent MRI were also screened for three known mutations of the hemochromatosis gene: the substitution of tyrosine for cysteine at position 282 (C282Y), the substitution of aspartic acid for histidine at position $63(\mathrm{H} 63 \mathrm{D})$, and the substitution of cysteine for serine at position 65 (S65C). The C282Y mutation creates a new SnaBI site, whereas the H63D and S65C mutations remove an MboI and HinfI site, respectively, in PCR-amplified DNA. ${ }^{16,17}$

\section{Statistical Analysis}

Statistical analyses were conducted with an SSPS software program. Student's t-test was used to compare continuous data, and the chi-square test was used for categorical variables. Spearman's correlation coefficient was used to express the correlation between variables.

\section{RESULTS}

\section{Genotypes}

Table 1 lists the frequencies of various hemoglobin $\mathrm{H}$ genotypes among the 114 patients. There were $87(/-\alpha)$ and $27\left(/ \alpha \alpha^{\mathrm{T}}\right)$ haplotypes. In all but one of the patients, a $20-\mathrm{kb}$ deletion that is typical of $\alpha$-thalassemia in patients in Southeast Asia accounted for the $(--/)$ haplotypes; in the remaining patient, the entire cluster of genes related to the $\alpha$-globin locus was deleted. ${ }^{18}$ Among the deletional $(/-\alpha)$ haplotypes, a 3.7-kb deletion of the $\alpha$-globin genes $\left(/ \alpha^{-3.7}\right)$ affecting the rightward $\alpha \mathrm{l}$ gene accounted for about two thirds of cases, and a $4.2-\mathrm{kb}$ deletion $\left(/ \alpha^{-4.2}\right)$ affecting the leftward $\alpha 2$ gene made up the rest, including two that were associated with a structural mutation of the $\alpha$-globin gene (hemoglobin $\mathrm{Q}$ ). Among the nondeletional $\left(/ \alpha \alpha^{\mathrm{T}}\right)$ haplotypes, the Constant Spring variant was the most common, followed by the Quong Sze variant. Both are due to point mutations in the $\alpha$-globin gene, at codons 142 and 125, respectively. Four patients had a deletion at codon 30 of $\alpha 2$, and one had a mutation at codon 59 of $\alpha 2$. A novel mutation at codon 31 of $\alpha 2(\mathrm{AGG} \rightarrow \mathrm{AAG})$ was identified in two sisters.
Table 1. Frequency of Various Hemoglobin H Genotypes AMONG THE 114 PATIENTS.

\begin{tabular}{|c|c|c|}
\hline Type of Mutation & GenotyPe & $\begin{array}{c}\text { No. OF } \\
\text { Patients (\%) }\end{array}$ \\
\hline \multicolumn{3}{|l|}{ Deletion } \\
\hline $\begin{array}{l}\text { Rightward deletion of } 3.7 \mathrm{~kb} \text { of the } \\
\alpha \text {-globin gene }\end{array}$ & $--/-\alpha^{-3.7}$ & $64(56)$ \\
\hline Leftward deletion of $4.2 \mathrm{~kb}$ of $\alpha 2$ & $--/-\alpha^{-4.2}$ & $21(18)$ \\
\hline $\begin{array}{l}\text { Leftward deletion in gene for } \alpha \text {-globin } \\
\text { chain associated with hemoglobin Q }\end{array}$ & $--/-\alpha^{\mathrm{Q}}$ & $2(2)$ \\
\hline \multicolumn{3}{|l|}{ Nondeletion } \\
\hline $\begin{array}{l}\text { TAA } \rightarrow \text { CAA at codon } 142 \text { (hemo- } \\
\text { globin Constant Spring variant) }\end{array}$ & $--/ \alpha^{\mathrm{CS}} \alpha$ & $15(13)$ \\
\hline $\begin{array}{l}\text { CTG } \rightarrow \text { CCG at codon } 125 \text { (hemo- } \\
\text { globin Quong Sze variant) }\end{array}$ & $--\alpha^{\mathrm{QS}} \alpha$ & $5(4)$ \\
\hline$\Delta \mathrm{GAG}$ at codon 30 of $\alpha 2$ & $--/ \alpha^{\Delta 30} \alpha$ & $4(4)$ \\
\hline $\mathrm{AGG} \rightarrow \mathrm{AAG}$ at codon 31 of $\alpha 2$ & $--/ \alpha^{31} \alpha$ & $2(2)^{*}$ \\
\hline GGC $\rightarrow$ GAC at codon 59 of $\alpha 2$ & $--/ \alpha^{59} \alpha$ & $1(1)$ \\
\hline Total & & $114(100)$ \\
\hline
\end{tabular}

*Two sisters had this mutation.

\section{Clinical Features}

Hemoglobin $\mathrm{H}$ disease is usually of intermediate severity. Only 24 percent of the patients presented with symptoms directly related to the disease, such as jaundice ( 2 percent), symptoms of anemia (11 percent), and gallstones (11 percent). In most patients (76 percent), the diagnosis was made incidentally after they presented with infections, during a work-related health assessment, or on hematologic examination during pregnancy.

Of 77 adults who underwent ultrasonography, 26 had gallstones; 5 of these 26 underwent cholecystectomy. Among children, the rate of growth was below the third percentile for age in 13 percent. Neither gallstones nor growth retardation was related to the genotype. A few patients had very mild dysmorphic facial features. Of the 114 patients, 53 (46 percent) had been treated with transfusions. Except for the one patient who presented with hydrops fetalis as a result of the GGC $\rightarrow$ GAC mutation at codon 59 of the $\alpha 2$ gene, ${ }^{14}$ and who had been dependent on transfusions since undergoing transfusion in utero, the patients were not transfusion-dependent. The median number of transfusions was 1.4, and only eight patients had received 5 or more transfusions (median number, 5.5; range, 5 to 20). Two siblings with the Constant Spring variant and massive splenomegaly required regular transfusions until they underwent splenectomy. Other patients received transfusions because of anemia during pregnancy or infection.

Table 2 shows the clinical and laboratory findings in the patients. Patients with a nondeletional haplotype had more severe clinical features than patients with a deletional haplotype; a larger proportion of them were symptomatic at presentation (40 percent 
Table 2. Characteristics of 114 Patients with Hemoglobin H Disease, According to the Type of Mutation.*

\begin{tabular}{|c|c|c|c|}
\hline Characteristic & $\begin{array}{l}\text { Deletion } \\
(\mathbf{N}=87)\end{array}$ & $\begin{array}{l}\text { NONDELETION } \\
(\mathbf{N}=\mathbf{2 7})\end{array}$ & P Value \\
\hline $\begin{array}{l}\text { Age at diagnosis }(\mathrm{yr}) \\
\text { Mean } \\
\text { Median }\end{array}$ & $\begin{array}{c}22.6 \pm 16.9 \\
20\end{array}$ & $10.8 \pm 11.0$ & $<0.001$ \\
\hline Symptoms at presentation (\%) & 23 & 40 & 0.07 \\
\hline History of transfusion (\%) & 42 & 81 & $<0.001$ \\
\hline Abnormal liver function (\%) & 17 & 50 & 0.001 \\
\hline $\begin{array}{l}\text { Aspartate aminotransferase } \\
\text { (U/liter) }\end{array}$ & $25.1 \pm 11.0$ & $38.4 \pm 21$ & 0.001 \\
\hline Spleen size $(\mathrm{cm})$ & $1.52 \pm 1.99$ & $4.62 \pm 4.1$ & $<0.001$ \\
\hline Splenectomy (\%) & 5 & 31 & $<0.001$ \\
\hline Liver size $(\mathrm{cm})$ & $0.8 \pm 1.4$ & $1.2 \pm 1.6$ & 0.2 \\
\hline Lactate dehydrogenase (U/liter) & $442 \pm 193$ & $900 \pm 864$ & 0.004 \\
\hline Ferritin (ng/ml) & $536 \pm 649$ & $841 \pm 1000$ & 0.1 \\
\hline Signal-intensity ratio of liver & $0.52 \pm 0.52$ & $0.1 \pm 0.089$ & 0.002 \\
\hline Hemoglobin $(\mathrm{g} / \mathrm{dl})$ & $9.5 \pm 1.3$ & $8.4 \pm 1.6$ & 0.003 \\
\hline Red cells $\left(\times 10^{-6} / \mathrm{mm}^{3}\right)$ & $5.0 \pm 0.7$ & $4.1 \pm 0.7$ & $<0.001$ \\
\hline Mean corpuscular volume $\left(\mu \mathrm{m}^{3}\right)$ & $63.6 \pm 5.6$ & $73.8 \pm 6.7$ & $<0.001$ \\
\hline Mean corpuscular hemoglobin (pg) & $18.7 \pm 1.7$ & $20.2 \pm 1.8$ & 0.001 \\
\hline $\begin{array}{l}\text { Mean corpuscular hemoglobin } \\
\text { concentration }(\mathrm{g} / \mathrm{dl})\end{array}$ & $29.3 \pm 1.7$ & $27.3 \pm 2.4$ & 0.001 \\
\hline Reticulocytes (\%) & $4.2 \pm 2.5$ & $5.9 \pm 3.4$ & 0.03 \\
\hline Hemoglobin $\mathrm{H}(\%)$ & $7.3 \pm 3.6$ & $15.9 \pm 8.0$ & $<0.001$ \\
\hline Hemoglobin $\mathrm{A}_{2}(\%)$ & $1.2 \pm 0.1$ & $0.9 \pm 0.6$ & 0.002 \\
\hline Fetal hemoglobin (\%) & $1.3 \pm 0.64$ & $2.3 \pm 2.0$ & $<0.001$ \\
\hline Hemoglobin Bart's (\%) & $0.68 \pm 0.9$ & $2.7 \pm 2.5$ & $<0.001$ \\
\hline
\end{tabular}

*Plus-minus values are means \pm SD.

vs. 23 percent), were younger at diagnosis (mean, 10.8 vs. 22.6 years), had larger spleens ( 4.62 vs. 1.52 $\mathrm{cm})$ and were more likely to have received a transfusion ( 81 percent vs. 42 percent). They also had more severe anemia (hemoglobin level, 8.4 vs. $9.5 \mathrm{~g}$ per deciliter), had higher proportions of hemoglobin $\mathrm{H}$ (15.9 percent vs. 7.3 percent) and hemoglobin Bart's ( 2.7 percent vs. 0.68 percent), and more severe hemolysis, as indicated by higher mean corpuscular volumes $\left(73.8\right.$ vs. $\left.63.6 \mu \mathrm{m}^{3}\right)$, reticulocyte counts $(5.9$ vs. 4.2 percent), and lactate dehydrogenase levels (900 vs. $442 \mathrm{U}$ per liter).

All patients were screened for the glucose-6-phosphate dehydrogenase deficiency, and only three were positive for the deficiency. None of the three had more severe anemia than did patients without the deficiency.

\section{Iron Overload}

Figure $2 \mathrm{~A}$ shows the relation between serum ferritin levels and age. The ferritin level increased significantly with age $(\mathrm{P}<0.001)$ and was not related to transfusion history. There was no significant difference in results between male and female patients or
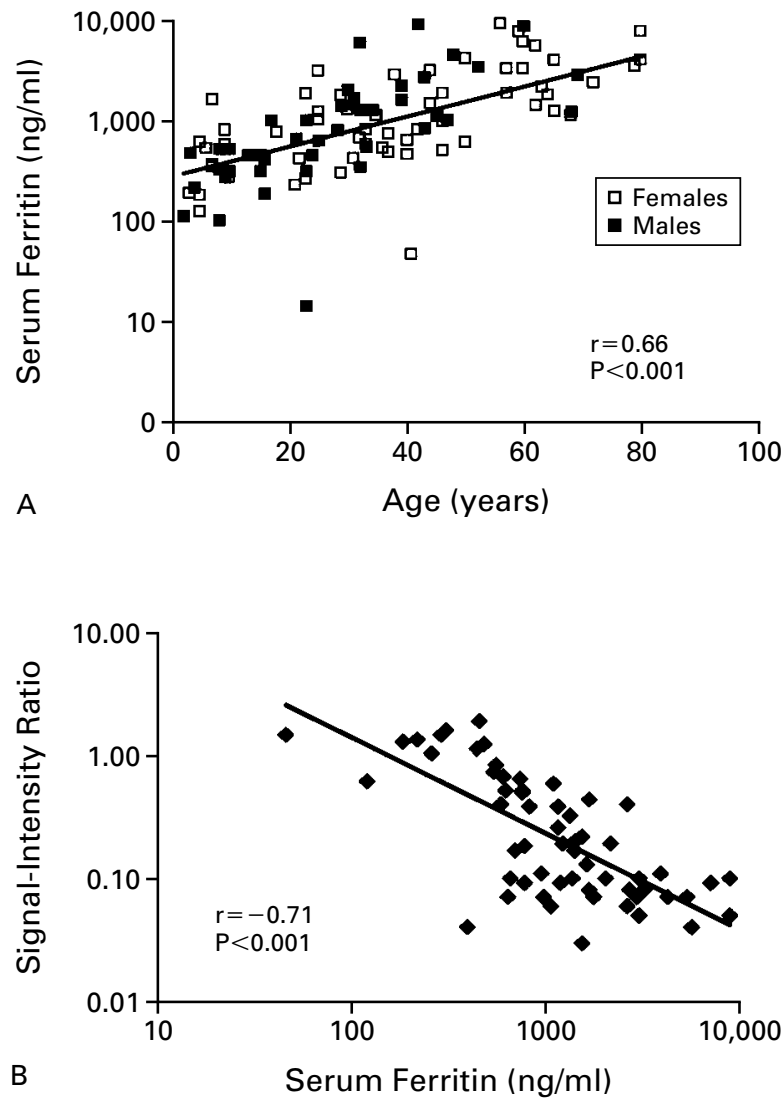

Figure 2. Correlation between Serum Ferritin Levels and the Age of the Patients (Panel A) and the Ratio of the Signal Intensity in the Liver to the Signal Intensity in Paraspinous Muscle on a $\mathrm{T}_{2}$-Weighted Gradient-Echo Magnetic Resonance Imaging Sequence (Panel B).

A signal-intensity ratio of less than 1 indicates iron overload.

between patients with deletional haplotypes and those with nondeletional haplotypes. MRI of the liver showed a signal-intensity ratio of less than 1 in 85 percent of the patients who underwent MRI ( 51 of $60)$, and there was an inverse relation between the ratio and serum ferritin levels $(\mathrm{P}<0.001)$ (Fig. 2B), indicating that liver iron content increased with higher ferritin levels. Liver biopsy performed in six patients who had elevated serum ferritin levels, abnormal liver function, or both (Table 3 ) showed fibrosis in five and cirrhosis in two. All six had a moderate or severe iron overload on qualitative MRI and quantitative MRI (mean signal-intensity ratio, $0.14 \pm 0.18$ ) and an abnormal liver iron content. All six patients had negative serologic tests for hepatitis B and C and other known causes of liver disease. None were receiving long-term iron therapy or herbal remedies.

Echocardiography in 25 patients who had no history or symptoms of heart failure showed a normal ejection fraction (mean, $62 \pm 7$ percent; range, 50 to 
Table 3. Liver-Biopsy Findings in Six Patients With InCREASEd Ferritin LeVELS, Abnormal Liver Function, or Both.

\begin{tabular}{|c|c|c|c|c|c|c|}
\hline \multirow[t]{2}{*}{$\begin{array}{c}\text { Patient } \\
\text { No. }\end{array}$} & \multirow[t]{2}{*}{$\begin{array}{l}\text { SEX/ } \\
\text { AGE } \\
\text { (YR) }\end{array}$} & \multirow[t]{2}{*}{$\begin{array}{l}\text { FERRITIN } \\
\text { (ng/ml) }\end{array}$} & \multirow[t]{2}{*}{$\begin{array}{c}\text { GRADE } \\
\text { OF IRON } \\
\text { OVERLOAD } \\
\text { ON MRI* }\end{array}$} & \multicolumn{3}{|c|}{ LIVER-BIOPSY FINDINGS } \\
\hline & & & & FIBROSIS & CIRRHOSIS & IRON† \\
\hline 1 & $\mathrm{~F} / 31$ & $304 \ddagger$ & Moderate & Minimal & Absent & II \\
\hline 2 & $\mathrm{~F} / 44$ & 1168 & Severe & Mild & Absent & II \\
\hline 3 & $\mathrm{~F} / 57$ & 1232 & Severe & Absent & Absent & II \\
\hline 4 & $\mathrm{~F} / 60$ & 2240 & Severe & Minimal & Absent & III \\
\hline 5 & $\mathrm{~F} / 59$ & 2880 & Severe & Severe & Early & IV \\
\hline 6 & $\mathrm{~F} / 55$ & 3560 & Severe & Very severe & Established & IV \\
\hline $\begin{array}{r}\text { Normal } \\
\text { values }\end{array}$ & & $6-353$ & Normal & Absent & Absent & I \\
\hline
\end{tabular}

* The degree of iron overload was assessed according to the method of Ooi et al. ${ }^{10}$

†The amount of iron in the liver was assessed with use of a four-point scale in which a grade of I indicates normal levels and grades of II, III, and IV increasing amounts of iron. ${ }^{12}$

$\ddagger$ Patient 1 had had recent gastrointestinal bleeding.

74 percent). However, the diastolic function was not in the normal range derived from assessments of 25 normal age-matched controls. The ratio of the peak velocity of blood flow across the mitral valve in early diastole to that in late diastole as a result of atrial contraction was $2.01 \pm 0.88$ in the patients, as compared with $1.34 \pm 0.40$ in the controls $(\mathrm{P}<0.001)$. The isovolumic relaxation time was $64.8 \pm 11.5 \mathrm{msec}$ in the patients, as compared with $88.7 \pm 13.5 \mathrm{msec}$ in the controls $(\mathrm{P}<0.001)$. Moreover, an increase in serum ferritin levels was significantly related to a decrease in the ratio of the peak velocity of blood flow across the mitral valve in early diastole to that in late diastole as a result of atrial contraction $(\mathrm{P}=0.007)$ and to an increase in the isovolumic relaxation time $(\mathrm{P}=0.04)$ (Fig. 3).

None of the patients studied by MRI or echocardiography carried the $\mathrm{C} 282 \mathrm{Y}$ or the S65C mutation in the hemochromatosis gene. One patient was heterozygous for the H63D mutation, and his serum ferritin level was $1750 \mathrm{ng}$ per milliliter.

\section{DISCUSSION}

The clinical variability of hemoglobin $\mathrm{H}$ disease in Hong Kong can be explained in part by the diversity of genetic abnormalities that can cause the disease. Of the 114 patients we studied, 76 percent had the deletional genotype, and 24 percent had the nondeletional genotype. As in many other genetic diseases, the incidence of genetic subtypes of hemoglobin $\mathrm{H}$ disease varies in different ethnic groups. By contrast with our patients from southern China, those in Thai- land and Guangxi province (southwest of Guangdong, near Thailand) have a higher incidence of nondeletional hemoglobin $\mathrm{H}$ disease (40 to 60 percent). ${ }^{3,19}$

We confirmed ${ }^{20-24}$ that patients with nondeletional hemoglobin $\mathrm{H}$ disease have more severe anemia, hemolysis, and splenomegaly and are more likely to require transfusions than those with the deletional type of the disease. This clinical difference reflects a greater decrease in the synthesis of $\alpha$-globin chains in patients with nondeletional defects; in our study, most such mutations occurred in the $\alpha 2$ gene. The $\alpha 2$ gene normally controls the synthesis of three quarters of the $\alpha$-globin chains, whereas the downstream $\alpha \mathrm{l}$ gene controls one quarter. ${ }^{25,26}$ Mutant forms of the $\alpha 2$ gene probably retain normal transcriptional activity, but there is no protein product. Transcription of the mutant $\alpha 2$ gene interferes with transcription of the normal $\alpha \mathrm{l}$ gene, resulting in reduced synthesis of normal $\alpha$-globin chains. ${ }^{27}$ We found that the two types of deletional hemoglobin $\mathrm{H}$ disease, in which only one functional gene remained (either $\alpha 1$ or $\alpha 2$ ), are clinically similar, because in either situation, transcription of a single $\alpha$-globin gene can occur without interference.

Of the patients with nondeletional hemoglobin $\mathrm{H}$ disease, those with the Constant Spring variant have an additional mechanism for hemolysis because the variant chains damage the red-cell membrane directly, causing an increased influx of water that is followed by hemolysis. ${ }^{28,29}$ These chains also form tetramers with $\beta$-globin chains (creating hemoglobin Constant Spring), thereby reducing the number of free $\beta$-globin chains available to form $\beta$-globin tetramers (i.e., hemoglobin $\mathrm{H}$ ). Nevertheless, the mean hemoglobin $\mathrm{H}$ level in patients with the Constant Spring variant (12.3 \pm 4.8 percent) was higher than in patients with deletional hemoglobin $\mathrm{H}$ disease. Patients with the Quong Sze variant and those with the $\triangle$ GAG mutation at codon 30 of $\alpha 2$ had even higher hemoglobin $\mathrm{H}$ levels $(21.1 \pm 2.2$ percent and $21.9 \pm 7.5$ percent, respectively), because their mutant $\alpha$-globin chains are unstable, degrade rapidly, and do not form an abnormal hemoglobin with the excess $\beta$-globin chains. ${ }^{21,30}$

Since most patients with hemoglobin $\mathrm{H}$ disease lead normal lives and have treatable late complications, prenatal testing for the disease is usually unwarranted. However, hydrops fetalis has been reported in two fetuses, one with the GGC $\rightarrow$ GAC mutation at codon 59 of $\alpha 2$ and one with compound heterozygosity for the deletion of the $\zeta-\alpha$-globin gene cluster and the $\Delta$ GAG mutation at codon 30 of $\alpha 2 .{ }^{14,18,21}$ Prenatal diagnosis and termination of such affected pregnancies are advisable.

The major complications in patients with hemoglobin $\mathrm{H}$ disease result from iron overload. The increase in serum ferritin levels is correlated with age but is unrelated to the genotype. In 85 percent of the patients who underwent MRI of the liver, liver iron con- 

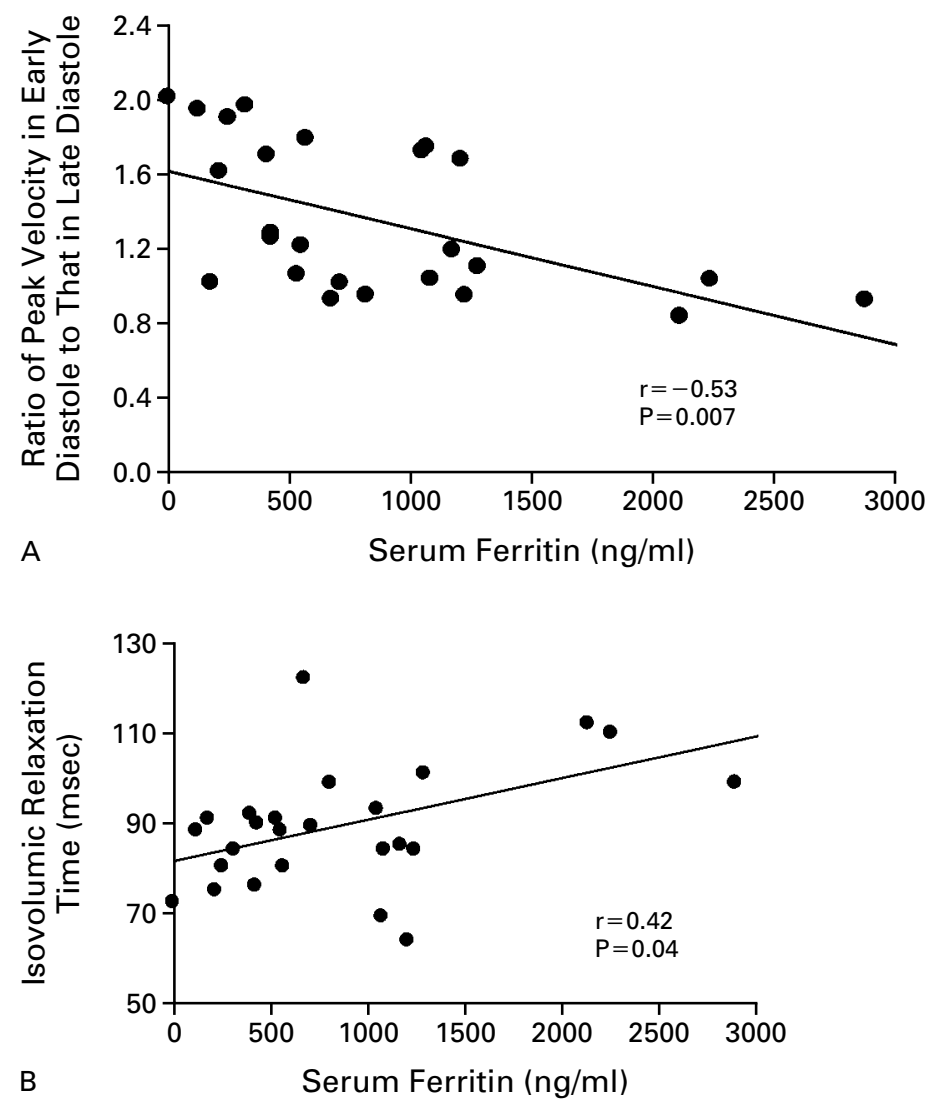

Figure 3. Relation between the Serum Ferritin Level and the Ratio of the Peak Velocity of Blood Flow across the Mitral Valve in Early Diastole to That in Late Diastole Due to Atrial Contraction (Panel A) and the Isovolumic Relaxation Time (Panel B).

$A$ ratio of less than 1 is suggestive of an impairment in left ventricular relaxation. An isovolumic relaxation time of more than $100 \mathrm{msec}$ is suggestive of abnormal left ventricular relaxation.

tent was also increased. The inverse relation between the signal-intensity ratio on MRI of the liver and serum ferritin levels indicates that hepatic iron content increases with age. MRI has also been used to detect iron overload in patients with hemochromatosis ${ }^{11,13}$ and transfusion-dependent thalassemia. ${ }^{31}$ The limitations of MRI are that it underestimates iron levels in organs if the levels are extremely high and that the signal intensity varies in patients with advanced cirrhosis. ${ }^{32,33}$ Neither of these problems was encountered in our patients.

In three of our patients with hemoglobin $\mathrm{H}$ disease, heart failure developed as a result of severe iron overload, although they had not received long-term transfusion therapy and they did not have any of the known mutations of the hemochromatosis gene or other contributing factors. Among the adult patients with asymptomatic hemoglobin $\mathrm{H}$ disease who underwent echocardiography in our study, diastolic function was abnormal and there was a trend toward in- creasing abnormality with increasing serum ferritin levels. Such abnormal diastolic function has been shown to precede left ventricular systolic dysfunction in patients with thalassemia major ${ }^{34,35}$; we can use these measurements to monitor patients with asymptomatic hemoglobin $\mathrm{H}$ disease before heart failure due to iron overload develops.

Iron overload in patients with hemoglobin $\mathrm{H}$ disease who do not require transfusions has been reported in other Asian patients, ${ }^{7-9}$ but not in patients of Mediterranean origin. ${ }^{36,37}$ The latter were children, and we have shown in the current study that iron overload is time-dependent. The coinheritance of hereditary hemochromatosis as a possible cause of iron overload was ruled out in all but one of our patients, who was found to be a carrier of the H63D mutation in the hemochromatosis gene, but his serum ferritin level was not significantly higher than that of the other patients. This incidence of the H63D mutation ( 1 in 60 , or 1.7 percent) in our group is similar to 
the 2.7 percent incidence reported among Chinese in Australia and is much lower than that among whites. ${ }^{38}$ For these reasons, iron overload in our group can best be explained by the increased absorption of dietary iron resulting from hemolysis and ineffective erythropoiesis. ${ }^{39}$

In patients with transfusion-dependent $\beta$-thalassemia major, iron deposits are mostly in the Goethite form, as opposed to the smaller ferrihydride form that occurs in patients with non-transfusiondependent thalassemia intermedia. ${ }^{40,41}$ The ferrihydride form causes more tissue damage, because it is less crystalline and releases more toxic oxygen free radicals. Therapeutic intervention may therefore be indicated at much lower ferritin levels in patients with non-transfusion-dependent thalassemia, such as hemoglobin $\mathrm{H}$ disease, than in patients with thalassemia major, for whom the threshold for starting chelation therapy is a serum ferritin level of 1000 ng per milliliter. Therefore, we propose that patients with hemoglobin $\mathrm{H}$ disease should be closely monitored for tissue damage due to iron overload, and chelation therapy should be initiated once such damage is detected.

Supported by the Croucher Foundation and the Committee on Research and Conference Grant of Hong Kong University.

We are indebted to the staff of the Clinical Biochemistry Unit and the Clinical Haematology Unit, Queen Mary Hospital, for performing routine blood tests in the patients.

\section{REFERENCES}

1. Chan V, Chan TK, Cheng MY, Kan YW, Todd D. Organization of $\zeta-\alpha$ genes in the Chinese. Br J Haematol 1986;64:97-105.

2. Lau Y-L, Chan L-C, Chan Y-YA, et al. Prevalence and genotypes of $\alpha$ - and $\beta$-thalassemia carriers in Hong Kong - implications for population screening. N Engl J Med 1997;336:1298-301.

3. Fucharoen S, Wasi P. Thalassaemia in Southeast Asia. In: Program \& abstracts of the 2nd International Conference on Thalassemia in China: Thalassemia in Millennium, Nanning Guangxi, China, October 13-16, 1998:3-4. abstract.

4. Rigas DA, Koler RD, Osgood EE. New hemoglobin possessing a higher electrophoretic mobility than normal adult hemoglobin. Science 1955 121:372.

5. Ager JAM, Lehmann H. Observations on some "fast" haemoglobins: K, J, N, and "Bart's." BMJ 1958;1:929-31.

6. Wickramasinghe SN, Hughes M, Hollan SR, Horanyi M, Szelenyi J. Electron microscope and high resolution autoradiographic studies of the erythroblasts in haemoglobin $\mathrm{H}$ disease. $\mathrm{Br} J$ Haematol 1980;45:401-4.

7. Tso SC, Loh TT, Todd D. Iron overload in patients with haemoglobin $\mathrm{H}$ disease. Scand J Haematol 1984;32:391-4.

8. Hsu HC, Lin CK, Tsay SH, et al. Iron overload in Chinese patients with hemoglobin $\mathrm{H}$ disease. Am J Hematol 1990;34:287-90.

9. Chim CS, Chan V, Todd D. Hemosiderosis with diabetes mellitus in untransfused hemoglobin H disease. Am J Hematol 1998;57:160-3.

10. Ooi GC, Chen FE, Chan KN, et al. Qualitative and quantitative magnetic resonance imaging in haemoglobin $\mathrm{H}$ disease: screening for iron overload. Clin Radiol 1999;54:98-102.

11. Gandon $Y$, Guyader D, Heautot JF, et al. Hemochromatosis: diagnosis and quantification of liver iron with gradient-echo MR imaging. Radiology 1994; 193:533-8

12. Chezmar J, Nelson RC, Malko JA, Bernardino ME. Hepatic iron overload: diagnosis and quantification by noninvasive imaging. Gastrointest Radiol 1990;15:27-31.

13. Siegelman ES, Mitchell DG, Outwater E, Munoz SJ, Rubin R. Idiopathic hemochromatosis: MR imaging findings in cirrhotic and precirrhotic patients. Radiology 1993;188:637-41

14. Chan V, Chan VWY, Tang M, Lau K, Todd D, Chan TK. Molecula defects in $\mathrm{Hb} \mathrm{H}$ hydrops fetalis. Br J Haematol 1997;96:224-8.
15. Chan V, Yam I, Chen FE, Chan TK. A reverse dot-blot method for rapid detection of non-deletion $\alpha$ thalassaemia. Br J Haematol 1999;104: 513-5.

16. Jazwinska EC, Cullen LM, Busfield F, et al. Haemochromatosis and HLA-H. Nat Genet 1996;14:249-51.

17. Mura C, Raguenes O, Ferec C. HFE mutations analysis in 711 hemochromatosis probands: evidence for $565 \mathrm{C}$ implication in mild form of hemochromatosis. Blood 1999;93:2502-5.

18. Chan V, Chan TK, Liang ST, Ghosh A, Kan YW, Todd D. Hydrops fetalis due to an unusual form of $\mathrm{Hb} \mathrm{H}$ disease. Blood 1985;66:224-8.

19. Chen P, Long G, Winichagoon P, Fucharoen S. Genotype and phenotype interaction of $\mathrm{Hb} \mathrm{H}$ disease in Guangxi Province, P. R. China. In: Program \& abstracts of the 2nd International Conference on Thalassemia in China: Thalassemia in Millennium, Nanning Guangxi, China, October 13-16, 1998:14. abstract.

20. Paglietti E, Galanello R, Moi P, Pirastu M, Cao A. Molecular pathology of haemoglobin H disease in Sardinians. Br J Haematol 1986;63:48596.

21. Chan V, Chan TK, Todd D. Different forms of $\mathrm{Hb} \mathrm{H}$ disease in the Chinese. Hemoglobin 1988;12:499-507.

22. Kattamis C, Tzotzos S, Kanavakis E, Synodinos J, Metaxotou-

Mavrommati A. Correlation of clinical phenotype to genotype in haemoglobin $\mathrm{H}$ disease. Lancet 1988;1:442-4.

23. Liu TC, Chiou SS, Lin SF, et al. Molecular basis and hematological characterization of $\mathrm{Hb} \mathrm{H}$ disease in Southeast Asia. Am J Hematol 1994; 45:293-7.

24. Torcharus K, Sriphaisal T, Krutvecho T, Suwanasophon C, Intarapakawong J. Clinical phenotypes and genotypes diagnosis of thalassaemia in children. Southeast Asian J Trop Med Public Health 1995;26:Suppl 1:2757.

25. Orkin SH, Goff SC. The duplicated human $\alpha$-globin genes: their relative expression as measured by RNA analysis. Cell 1981;24:345-51.

26. Liebhaber SA, Cash FE, Ballas SK. Human $\alpha$-globin gene expression: the dominant role of the $\alpha 2$-locus in mRNA and protein synthesis. J Biol Chem 1986;261:15327-33.

27. Weatherall $D$. The molecular basis for phenotypic variability of the common thalassaemias. Mol Med Today 1995;1:15-20.

28. Peerapittayamongkol C, Bernini LF, Wilairat P. Presence of $\alpha^{\mathrm{Cs}}$ globin on membrane of red cells containing hemoglobin constant spring (CS). J Sci Soc Thailand 1996;22:117-20.

29. Schrier SL, Bunyaratvej A, Khuhapinant A, et al. The unusual pathobiology of hemoglobin Constant Spring red blood cells. Blood 1997;89: $1762-9$

30. Goossens M, Lee KY, Liebhaber SA, Kan YW. Globin structural mutant $\alpha 125^{\text {Leu } \rightarrow \text { Pro }}$ is a novel cause of $\alpha$ thalassaemia. Nature 1982;296:864 5 .

31. Bonetti MG, Castriota-Scanderbeg A, Criconia GM, et al. Hepatic iron overload in thalassemic patients: proposal and validation of an MRI method of assessment. Pediatr Radiol 1996;26:650-6.

32. Angelucci E, Giovagnoni A, Valeri G, et al. Limitations of magnetic resonance imaging in measurement of hepatic iron. Blood 1997;90:4736 42.

33. Guyader D, Gandon Y, Robert JY, et al. Magnetic resonance imaging and assessment of liver iron content in genetic hemochromatosis. Hepatology 1992;15:304-8

34. Senior R, Batabyal SK, Dutta RN, et al. An echo-cardiographic (M-mode \& 2D) analysis of thalassaemia major. Indian Heart J 1990;42: 73-6.

35. Yaprak I, Aksit S, Ozturk C, Bakiler AR, Dorak C, Turker M. Left ventricular diastolic abnormalities in children with beta-thalassemia major: a Doppler echocardiographic study. Turk J Pediatr 1998;40:201-9.

36. Galanello R, Melis MA, Paglietti E, Cornacchia G, de Virgiliis S, Cao A. Serum ferritin levels in hemoglobin $\mathrm{H}$ disease. Acta Haematol 1983;69:56-8. 37. Galanello R, Pirastu M, Melis MA, Paglietti E, Moi P, Cao A. Phenotype-genotype correlation in haemoglobin $\mathrm{H}$ disease in childhood. J Med Genet 1983;20:425-9

38. Cullen LM, Gao X, Easteal S, Jazwinska EC. The hemochromatosis $845 \mathrm{G} \rightarrow \mathrm{A}$ and $187 \mathrm{C} \rightarrow \mathrm{G}$ mutations: prevalence in non-Caucasian populations. Am J Hum Genet 1998;62:1403-7.

39. Pippard MJ, Callender ST, Warner GT, Weatherall DJ. Iron absorption and loading in beta-thalassaemia intermedia. Lancet 1979;2:819-21.

40. St Pierre TG, Chua-anusorn W, Webb J, Macey D, Pootrakul P. The form of iron oxide deposits in thalassemic tissues varies between different groups of patients: a comparison between Thai $\beta$-thalassemia/hemoglobin E patients and Australian $\beta$-thalassemia patients. Biochim Biophys Acta 1998; 1407:51-60.

41. Chua-anusorn W, St Pierre TJ, Webb J, Macey DJ, Yansukon P, Pootrakul P. Moessbauer spectroscopic study of the forms of iron in normal liver and spleen tissue, iron oxides formed in thalassaemia tissue. Hyperfine Interaction 1994;9:905-10. 